\title{
Cysteine Protease ATG4C
}

National Cancer Institute

\section{Source}

National Cancer Institute. Cysteine Protease AT G4C. NCI Thesaurus. Code C114675.

Cysteine protease AT G4C (458 aa, $\sim 52 \mathrm{kDa}$ ) is encoded by the human AT G4C gene. This protein plays a role in proteolysis of autophagy-regulatory proteins. 